\title{
Translation Challenges
} in Rendering Idiolects of Literary Characters Literatūrinių personažų idiolektų vertimo iššūkiai

\section{TRANSLATION / VERTIMAS}

\section{Olha Sung}

Kyiv National Linguistic University, Ukraine
SAL $37 / 2020$

Translation

Challenges in

Rendering Idiolects of Literary Characters

Received 11/2019

Accepted 10/2020 crossef http://dx.doi.org/10.5755/j01.sal.1.37.24772

The article focuses on the challenges in rendering idiolects of literary characters. Idiolect as a means of speech characterisation of personages enables the researchers to see personages as linguistic personalities. Idiolects can fulfil several functions: comparative, psychological, distinctive, and characterising. It is shown that an integral character image is only possible to depict taking into consideration the specific features of characters' idiolects, which help the reader to discern a character's social status, age, educational background, gender, and emotional state. The aim of the article is to identify the challenges in rendering idiolects of literary characters, such as phonetic distortion of words, non-equivalent lexis, and non-standard syntax and to examine the relevant translation strategies and tactics of idiolect reproduction. Based on a comparative analysis of the original and translated texts, the research yielded a number of translation strategies such as the strategy of maximum preservation of idiolect characteristics and the strategy of partial preservation of idiolect characteristics. In the framework of the strategy of maximum preservation of idiolect characteristics, the tactic of parallel translation, the tactic of applying functional equivalents and the tactic of phonetic matching are singled out. In the framework of the strategy of partial preservation of idiolect characteristics, the tactics of compensation, omission, preservation, and substitution are singled out.

KEYWORDS: literary translation, literary character, hyperlect, idiolect, linguistic personality, translation strategy, translation tactic.

The translation of fiction remains one of the most challenging fields in translation theory. On the one hand, it gives a great impulse to the development of cultural communication and exchange. On the other hand, the "transfer from culture to culture" (Bassnett \& Lefevere, 1990) can lead to a certain misinterpretation of the author's intent. In order to address this complexity, theoreticians and practitioners of translation studies increasingly investigate literary texts within the framework of comparative linguistics, applying the methodology of other disciplines, i.e., cultural studies, psycholinguistics, and communication theory (Saldanha \& O'Brien, 2013). It proves that the study of the literary text acquires a new perspective due to the modern linguistic principals of multidisciplinarity and anthropocentrism (Kubryakova, 1995). In particular, the analysis of the text within the framework of functional aspect (Fedorov, 2002) acquires relevance. In linguistic research of literary texts, the study of such categories as "linguistic personality" (Karaulov, 1987), "idiostyle of literary personality" (Vo-

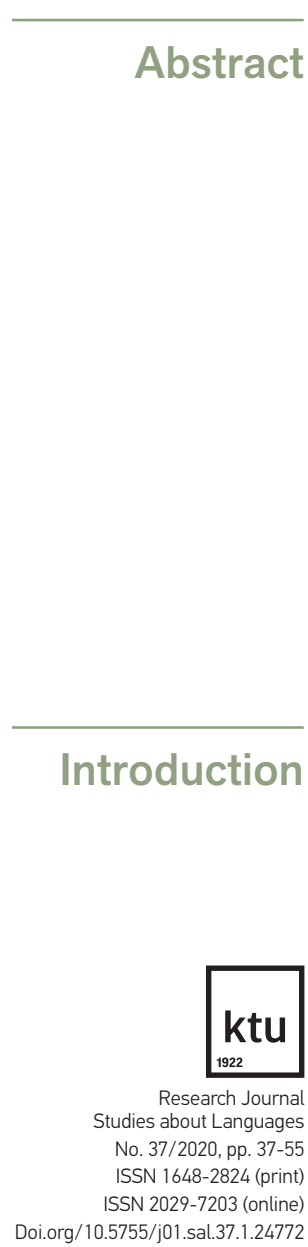


rozhbitova, 2007), "idiolect of literary character" (Korobleva, 2017; Lyutikova, 2000; Rybicki, 2006) in recent years get into the limelight.

The notion of "linguistic personality" (Karaulov, 1987) has been given close scrutiny in linguistics, particularly in sociolinguistics, psycholinguistics, and linguocultural studies (Karasik, 2002; Naumov, 2006; Leontiev. 2003). The notion of "linguistic personality" is closely related to the notion of idiolect. Each linguistic personality can be investigated through her/ his idiolect. From Bogdanova's (2011) standpoint, the notion of linguistic personality is a more general and abstract notion, while idiolect is related to a concrete person or literary character. Thus, when analysing speech of literary characters, researchers investigate their idiolect, bearing in mind the notion of linguistic personality as a general one.

In translation studies, the ways of rendering idiolects of literary characters are of an interest for modern researchers and translators (Ivushkina, 1998; Korobleva, 2017; Kukharenko, 2003; Nekriach, 2015; Popovych, 2015; Rebrii, 2012; Shcherbak, 2015). Due to the multiplicity of interpretations (Salzmann, 2007; Bogdanova, 2011) and the increasing number of works on literary translation (Andrienko, 2016; Formica, 2006; Nekriach, 2002; etc.), a universal definition of idiolect has not yet been formulated. Researchers are currently in dispute over the structure, functions, typological variations of idiolects and their manifestations in a literary text (Borunov \& Malygin, 2013; Sackmann, 2008, etc.). It proves that the problem of looking into idiolects is a topical issue that makes our research relevant and immediate. The research novelty is explained by an interest of modern translation studies in the investigation of idiolects within the functional, anthropocentric, and multidisciplinary approaches to the text interpretation. This new perspective allows investigating literary characters as linguistic personalities. Thus, deeper understanding of literary characters' idiolects helps translators to choose optimal translation strategies and tactics for faithful reproduction of literary character's speech.

The aim of the article is to identify the challenges in rendering idiolects of literary characters, such as phonetic distortion of words, non-equivalent lexis, non-standard syntax, and to examine the relevant translation strategies and tactics applied in the Russian and Ukrainian translations of J. D. Salinger's short story "For Esme With Love and Squalor". To achieve the aim, the following objectives were set:

- to define the concepts of idiolect of literary characters and linguistic personality, to elaborate on the functions of idiolect;

- to examine the characteristic features of typological variations of idiolect, based on the two sociolects (hyperlect :: non-literary speech);

- to identify the components of idiolect that represent challenges in translation at phonetic, lexical, grammatical levels (phonetic distortion of words, non-equivalent lexis, non-standard syntax);

- to highlight the specific translation strategies and tactics in rendering idiolects of literary characters (the strategy of maximum preservation of idiolect characteristics, the strategy of partial preservation of idiolect characteristics, the tactic of parallel translation, the tactic of phonetic matching, the tactic of applying the functional equivalents, compensation, omission, preservation, substitution).

Theoretical Background

\section{Linguistic and Translation Aspects of the Notion of Idiolect and its Functions}

One of the characteristic features of modern linguistics is a detailed investigation of the human factor in language activity (Karasik, 2002; Karaulov, 1987). The linguists' appeal to anthropocentrism results in the recognition of the leading role of a human being in the processes of language formation (Leontiev, 2003). The concept of linguistic personality has gained 
interest in the multidisciplinary research in linguistics, particularly in sociolinguistics, psycholinguistics, linguacultural studies, and translation studies.

In linguistics, the study of the concept "linguistic personality" was initiated by Karaulov, who introduced the classic three-level model of linguistic personality, which consists of the verbal-semantic, linguocognitive, and motivational levels (Karaulov, 1987, p. 52). From the perspective of linguacultural studies, linguistic personality is primarily a bearer of national culture. According to Karasik (2002, p. 2), linguistic personality is a person who exists in the language space, in communication, and in the stereotypes of behaviour that are recorded in the language, in the meanings of linguistic units and of texts. In sociolinguistics, linguistic personality is understood as a native speaker, who is "capable of manifesting a set of language means, which characterizes a definite language community (social group)" (Naumov, 2006, p. 11). Psycholinguistics investigates a speech behaviour of linguistic personalities depending on a psychological type they belong to (Leontiev, 2003).

Vorozhbitova's idea that the concept of "linguistic personality" plays an enormous role in a deeper understanding and analysis of the literary character (Vorozhbitova, 2007) is crucial for translation studies. On this basis, it becomes possible to identify and analyse a literary character as a linguistic personality, alongside with the identification of author's intentions, explicated and implicated in literary texts. Furthermore, we share Tarnaeva's (2008) and Rodionova's (2018) standpoint that the exploration of the language of literary texts through the analysis of literary characters' idiolects is one of the relevant tasks of modern linguistics, in particular of translation studies. Thus, the concept of linguistic personality helps to examine the characteristic traits of their idiolects more precisely. According to Bogdanov (2011, p. 102), linguistic personality is a more general notion than idiolect and finds its manifestation in the concrete idiolect of a literary character. Idiolect can reveal the character's social status, age, level of education, national identity, gender, social and professional affiliation.

This literature review contains a definition of idiolect as "the speech variety, or linguistic system, used by a particular individual, language variety unique to a specific speaker of a language" (Salzmann, 2007, p. 175) and the following extended definition of idiolect:

Individual speech, which is characterized by the place of living, age, specialty, social status, and the general level of culture of a personality. Idiolect as a linguistic idiosyncrasy of a person does not only highlight the individual character, but also reveals the diverse aspects of language as a nation-wide phenomenon and its inexhaustible potential (Gromyak \& Kovaliv, 1997, p. 301).

The extended definition seems to be optimal for our research and allows viewing the notion of idiolect as a powerful means of the speech characterisation of fiction personages.

Applying the multidisciplinary approach to text interpretation in our research makes it possible to investigate the linguistic and translation aspects of idiolect. In the linguistic aspect, idiolect is considered as a certain system, which includes six components: phonetic, phonological, morphological, syntactic, lexico-semantic, and sentence-semantic (Sackmann, 2008, p. 5). Bearing this in mind, our research is focused on the analysis of phonetic, lexical, and syntactical components of idiolect of literary characters. The deviations from the literary norm on these levels represent definite translation challenges, such as phonetic distortion of words, non-equivalent lexis, and non-standard syntax (Komissarov, 1990; Vlakhov \& Florin, 1980).

In the translation aspect, the functions of idiolect and the choice of translation strategies and tactics of rendering the specific features of idiolect are under the interest of researchers. Translators should bear in mind that idiolect as means of speech characterisation in literary prose can ful- 
fil a wide range of functions. Borunov and Malygin (2013) single out characterising, distinctive, comparative, and psychological functions of speech characterisation of literary characters. The characterising function finds its realisation in displaying the individual traits of the personage, their social status, gender, age, and birthplace. The distinctive function is intended to highlight the difference between idiolects of literary characters and create unforgettable imagery. The comparative function helps to compare the literary characters' idiolects in one and the same episode. The psychological function reveals the emotional and psychological state of characters. The psychological function of speech characterisation is also emphasised by Shcherbak (2015, p. 25): "Idiolect helps to reveal the inner world of the character, deepening the understanding of the character's psychology." Translators of fiction should base the text analysis on the assumption that idiolects fulfil those functions to embody the writer's worldview and intended message.

Thus, the task of a translator is to analyse the linguistic and translation aspects of idiolects of literary characters and to apply appropriate translation strategies and tactics for the faithful reproduction of idiolects. In our research, we support Nekriach's definitions of translation strategy and tactic. "Translation strategy is a general plan of action chosen by a particular translator, while translation tactics denote a specific fashion of solving a particular translation problem in the microcontext within a chosen translation strategy" (Nekriach, 2015, p. 42). Andrienko (2016, p. 224) also emphasises that "in the actual process of translation, strategies are implemented through tactics, which in their turn, determine procedures and shifts in translation." Korobleva (2010, p. 202-208) singles out three translation strategies of rendering idiolects of literary characters:

1 the strategy of maximum preservation of idiolect characteristics;

2 the strategy of partial preservation of idiolect characteristics;

3 the strategy of the complete ignoring of idiolect characteristics. In the framework of the strategy of maximum preservation of idiolect characteristics, several translation tactics such as the tactic of applying functional equivalents, the tactic of phonetic matching, and the tactic of word formation are singled out (Korobleva, 2010, p. 161-162).

In the framework of the strategy of partial preservation of idiolect characteristics, the tactic of compensation is widely used by the translators. The strategy of complete ignoring of idiolect characteristics does not imply any translation tactics, since the specific features of idiolects are consciously neutralised by the translators (Korobleva, 2010). Rebrii singles out two main approaches of fiction translation: the parallel translation approach and the compensational approach (Rebrii, 2012). These approaches can correlate with the strategies of maximum and partial preservation of idiolect characteristics. From the standpoint of Rebrii, fiction translators should resort to the parallel translation approach (Rebrii, 2012). This approach implies that translators will apply the same language means as those used by the author of the original text. For example, the phonetic violation of the source text (ST) will be rendered with the help of the phonetic violation of the target text (TT). However, Rebrii rightly notes that due to the structural differences between the target language (TL) and the source language (SL), it is impossible to fully reproduce individual speech of characters at all language levels. In this case, it is advisable to resort to the compensational approach (Rebrii, 2012). The compensational approach implies the application of such translation tactics as substitution, preservation and omission.

With this in mind, in the practical part of the research, we analyse the short story of J. D. Salinger and its Russian and Ukrainian translations in order to highlight the specific translation strategies and tactics in rendering idiolects of literary characters and to evaluate the gains and losses of these translation strategies and tactics. 
The linguistic variability is one of the general characteristic features of all national languages. Social stratification and regional distribution of society correspond to the vertical and horizontal differentiations of the language. Vertical differentiation highlights the affiliation of speakers to certain social or professional groups, while horizontal differentiation implies the division into local dialects. Vinogradov's (1990) study found out that idiolect is a representative of the definite sociolect or dialect. Thus, typological variations of idiolect such as sociolect and dialect can be singled out. In literary works, sociolects and dialects can be created with the help of "deviation from the literary norm" (Vlakhov \& Florin, 1980) or "substandard language" (Komissarov, 1990). "Substandard language is represented in the form of territorial, social, and contaminated (imitating a foreigner's speech) deviations from the literary norm" (Komissarov, 1990, p. 216). Creative writers resort to the deviations from the literary norm in order to reproduce the lexical, phonetic and grammatical features of everyday speech as close to the natural speech as possible. Vlakhov and Florin (1980) proposed to classify the deviations from the literary norm into collective (colloquialisms, dialects, jargon, argot, slang, professional language) and individual (the license of oral speech, children's speech, broken speech, the mistakes in spelling and pronunciation, speech defects such as inarticulateness, lisping, whining, speaking through the nose, speaking with a burr, whispering, stuttering) (Vlahkov \& Florin, 1980, p. 251). Thus, idiolect can include the collective features of definite sociolects or dialects as well as individual features, such as contaminated speech, speech defects, etc. It gives grounds to investigate sociolect, dialect, and contaminated speech as typological variations of idiolect.

In particular, our research is aimed to compare the specific traits of two sociolects, i.e., hyperlect and non-literary speech, and to highlight their phonetic, lexical and grammatical components that cause challenges for translators. Thus, phonetic distortions of words, non-equivalent lexis, nonstandard syntax are always challenging for fiction translators. Due to linguistic asymmetry between $\mathrm{SL}$ and $\mathrm{TL}$, there are no means to transfer the phonetic and grammatical deviations and non-equivalent lexis from SL in TL (Nekriach \& Kopyl'na, 2002). Moreover, the universal translation solution for rendering these challenges is not found. The translators use various means of reproducing these components of idiolect. From Shcherback's (2015, p. 25) standpoint, a particular technique can produce a positive result in one text, but the same deviation from the standard speech requires a different approach in another text depending on various factors. Thus, the translation tactics in rendering fiction idiolects cannot be unified and the choice depends on translator's special skills.

Creative writers frequently construct idiolects of personages in a contrast to each other. Thus, the oppositions "dialect :: literary norm" or "sociolect :: literary norm" can be intended by the author in order to create vivid imagery. Such opposition can be exemplified by a short story of J. D. Salinger (1953) "For Esme With Love and Squalor". The investigation into sociolects of its characters allows tracing the major opposition "hyperlect :: nonliterary speech". Hyperlect as a typological variation of sociolect is widely used in British aristocratic circles, with their received pronunciation (RP).

Honey (1998) singles out five forms of pronunciation in contemporary British English: hyperlect - the socially privileged marked RP accent, acrolect - high prestige or the standard variety, basilect - the broadest form of popular speech among the elderly people with little education, mesolect - the broadest possible accent form, paralect - a variety very close to RP but retaining a few tiny non-standard features (Honey, 1998, p. 96). Honey (1997) claims that the term hyperlect can cover not only accent but may also refer to the complete range of accent, grammar, vocabulary, and figures of speech, which constitute a social dialect. "The hyperlect is characterized by a luxuriant proliferation of forms of grammar, vocabulary, idiom and accent" (Honey, 1997, p. 236). 


\section{Methodology}

\section{Results and} Discussions
Oxford Dictionary of English Grammar gives the following definition of hyperlect: "A variety of language associated with the upper strata of society. The term is intended to cover marked grammatical usage as well as marked accent" (Chalker et al., 1994, p. 190). According to Ivushkina (1998, p. 105), the English aristocratic speech abounds in the use of bookish and abstract vocabulary, old-style and archaic words, inclusion of foreign speech and slang words, euphemisms, biblical, historical, literary and mythological allusions, which can enable us to regard it as a typical representative of hyperlect.

Having analysed all the definitions, we may conclude that hyperlect is regarded to be the most prestigious social variety of language, which embraces pronunciation, grammar, vocabulary and idioms, constituting a sociolect of the upper strata of society. Non-literary speech as another specimen of sociolect is characterised by deviations from the literary norm on all language levels. Non-literary speech indicates a low social status and a lack of education of literary characters.

Our research was based on the modern linguistic principals of multidisciplinarity and anthropocentrism (Kubryakova, 1995). In addition, the functional approach (Fedorov, 2002) to the analysis and interpretation of a literary text was applied in research. The functional approach gave us the opportunity to see the text as a dynamic system of relations between the author and the reader (Korobleva 2010, p. 208) and to distinguish the specific features of personages' idiolects and idiolect functions. By way of the multidisciplinary approach, we analysed the linguistic and translation aspects of idiolect. Within the anthropocentric approach, Karaulov's theory of linguistic personality for description idiolects of the literary character was applied in the research.

The main linguistic method of our research is a comparative analysis (Koptilov, 1982), which is complemented by contextual (Rebrii, 2012), stylistic (Matsko, 2003) and translation (Rybicki, 2006) analyses during the different stages of our research. Among general methods of the research, we applied induction, deduction, the method of quantitative estimate, and the continuous sampling method. These methods have proved their effectiveness in obtaining the quantitative indicators of the strategies and tactics analysed.

The research has been conducted in three stages. At the first stage, by way of the continuous sampling method, we collected the material of our research and worked out the research methodology. At the second stage, idiolects of the characters and their phonetic, lexical, and grammatical components in TT and ST were analysed. At this stage, contextual and stylistic analysis were employed in the research. By way of stylistic analysis, it was possible to determine the extent of stylistic violations in the TT caused by the linguistic and cultural asymmetry of $S L$ and $T L$ and unappropriated substitution of the stylistically marked vocabulary by neutral lexis in the characters' speech. By way of a contextual analysis, we investigated the presence of a "horizontal" (verbal) and "vertical" (situational) context and the influence of extralinguistic factors (i.e., context, time of translation) on the choice of translation strategies and tactics. At the final stage of our research, we applied the translation analysis of the original text and its translations into Ukrainian and Russian to describe the research results and to evaluate the translation strategies and tactics used for representing idiolects of literary characters.

\section{The Characteristic Traits of Esme's Idiolect}

The short story "For Esme With Love and Squalor" (Salinger, 1953) and its Ukrainian (Grygorenko \& Ivakhnenko, 2012) and Russian (Mitina, 1983) translations are in the focus of the present research of sociolect as a typological variation of idiolect. The author is known for his talent to create the stories of individual human relationships, to accentuate every detail of speech portraits of his characters, to reveal their linguistic personalities to the fullest extent possible. Salinger strives to reflect the real life of his characters, traumatic impact of the war 
and hope for humanity. The title character, Esme, a 13-year-old girl, tells the narrator about her past and her family in a very expressive speech style, impressing the narrator with her intelligence and manner of speech, not at all typical for her age. The life of Esme and her little brother was changed dramatically by the war, as both their parents died. Esme sought to conceal her immaturity and naivety by her affected poise and sophisticated manners.

Esme's idiolect is represented in the form of sociolect of the upper strata of society, which can be regarded as hyperlect. Esme's hyperlect is characterised by the use of bookish vocabulary, inclusions of foreign words of Latin and French origin, informal words, evaluative adjectives, repetition of the intensifiers quite, extremely, terribly and other verbal repetitions. Esme makes some mistakes in complex words, which can be regarded as a characteristic feature of her idiolect. Talking to her brother Charles, she imitates the adult speech, using imperatives. All these specific traits of Esme's idiolect are socially marked and require the exact rendering on the phonetic, lexical and syntactical levels in translation.

When analysing the specific traits of Esme's idiolect on the phonetic level, it should be mentioned that her speech abounds in complex words, some of them being used with the phonetic mistakes. She uses them to demonstrate her adulthood, although mistakes in these words indicate her young age and confusion of their meaning. While rendering the misused words, the translators come across such a translation challenge as phonetic distortion of words. The following excerpts contain the misused words:

(1) Eng.: Purely, as a momento of course (Salinger, 1953, p. 151).

Rus.: Разумеется, просто в качестве су-ве-ре-на (Salinger, 1983, р. 43).

Ukr.: Лише дарунок на пам'ять (Salinger, 2012, p. 114).

(2) Eng.: He had terribly penetrating eyes, for a man who was intransically kind (Salinger, 1953, p.149).

Rus.: У его был ужасно пронзительный взгляд для человека с такой им-момент-но присущей добротой (Salinger, 1983, p. 42).

Ukr.: У нього був украй пронизливий погляд, як на людину, яка добра за своєю природою (Salinger, 2012, р. 113).

The word momento is Esme's erroneous version of the word of Latin origin "memento" with the meaning of a souvenir. Esme makes a mistake using the adverb intrinsically and pronounces it as intransically. Due to her young age, Esme makes mistakes in sophisticated foreign words and does not understand the meaning of the word squalor, which is essential for the story. These mistakes can be regarded as the age markers and help the author to construct Esme's unique linguistic personality. The Russian translator successfully copes with the task, playing on the similarity of the words сувенир - суверен (souvenir - sovereign); the word им-мо-мент-но (im-momently) is reproduced by analogy with the original text. Thus, the tactic of phonetic matching is appropriately used in the Russian translation. The Ukrainian translators use the tactic of omission in rendering the phonetic mistakes; therefore, the stylistic value of these words is weakened in translation. This translation choice can be explained by a challenge to find the appropriate equivalents in the Ukrainian language.

Moving on to the analysis of the lexical level of Esme's idiolect, it should be mentioned that there are a lot of inclusions of foreign words of Latin and French origin, which can be regarded as the markers of social status. Babkin's (1966) study found out that foreign inclusions in the speech of characters "create the impression of erudition and wide reading" (Babkin, cited in Vlakhov et al., 1980, p. 236). For this reason, another character of the story Corporal Clay is asking the narrator to help to insert a foreign word in his letter to his girlfriend Loretta. According to Alekseitseva (2017), the inclusions of the foreign words can be preserved in TT without 
changes or can be reproduced with the help of transliteration. Transliteration can be applied in the case when the foreign inclusions are well-known for a target reader (Alekseitseva, 2017).

Among the inclusions of foreign words, there is the French phrase Il faut que je parte aussi (Salinger, 1953, p. 152), which is reproduced without translation in both variants, preserving this social marker of the high style. By presenting the translation of this phrase in the footnotes, the translators help the readers to understand the text without compromising its stylistic colouring. The explanatory footnotes are given in both translations, which can be regarded as the tactic of parallel translation in the explanatory footnotes. This tactic correlates with the strategy of maximum preservation of idiolect characteristics.

Another significant feature of Esme's hyperlect that presents difficulty in translation is the use of bookish words:

(3) Eng.: I am not terribly gregarious (Salinger, 1953, p. 144).

Rus.: Вообще-то мне не так уж свойственно стадное чувство (Salinger, 1983, p. 41).

Ukr.: Зазвичай, я не надто товариська (Salinger, 2012, p.109).

The word gregarious is a bookish word of Latin origin and in Esme's speech it appears as a social marker of hyperlect. Merriam-Webster Dictionary provides the following definition of this word:

gregarious - adjective. Etymology: Latin, gregarious of a flock or herd, from greg, grex flock, herd Date: 1668 1. a. tending to associate with others of one's kind; social; $\mathbf{b}$. marked by or indicating a liking for companionship; sociable; $\mathbf{c}$. of or relating to a social group.

In both translations, there are different approaches to preserve stylistic register of the word gregarious. The Russian translator uses the original Latin meaning of this word a herd and interprets the phrase as a herd instinct is unnatural for me, while the Ukrainian translation товариська/sociable is closer to the author's intendent meaning, if lacking its stylistic colouring. The Ukrainian translators provide a footnote stating the origin of the word, which can be regarded as the translator's conscious choice. A stylistic analysis of the other bookish words of Latin origin (introvert, extrovert, amateur, streptococcus, tremendously, ridiculous, virtues, novice) and French origin (archivist, hideous) proved that they are reproduced by appropriate equivalents in both translations. These words fulfil the characterising and distinctive functions, making Esme's speech unforgettable and unique. Thus, rendering bookish words, the Russian and Ukrainian translators resort to the strategy of maximum preservation of idiolect characteristics and the tactic of applying the functional equivalents to preserve stylistic colouring of the words.

The misuse of words is also a specific feature of Esme's idiolect. Esme makes mistakes not only in pronunciation of words, but also in their meaning. It can be demonstrated in the sentence with the word squalor:

(4) Eng.: I'm extremely interested in squalor (Salinger, 1953, p.151).

Rus.: Меня чрезвычайно интересует всякая мерзость (Salinger, 1983, p. 43).

Ukr.: Мені подобаються розповіді про всіляку мерзоту (Salinger, 2012, p.115).

Longman Dictionary of Contemporary English gives the following definition of the word squalor:

squalor - n. [Date: 1600-1700; Latin; Origin: squalere; SQUALID] the condition of being dirty and unpleasant because of a lack of care or money.

Thus, the word squalor is of Latin origin, that is why Esme refers it, erroneously, to the high register and seems to regard squalor as a kind of exciting challenge of the adult world. The 
author masterfully employs it in the title of his short story "For Esme with Love and Squalor" in order to grasp the reader's attention. The Russian word мерзость and the Ukrainian word мерзота are semantically and stylistically appropriate for the word squalor. In both variants of translation, the tactic of parallel translation is applied.

Another specific feature of Esme's speech is informal vocabulary, which contradicts her social poise. It can be illustrated in the following excerpts:

(5) Eng.: Heavens, no. I'm going to sing jazz on the radio and make heaps of money. (Salinger, 1953, p.141).

Rus.: Боже, нет, конечно. Я буду выступать с джазом по радио и зарабатывать кучу денег. (Salinger, 1983, р. 40).

Ukr.: Боже борони. Я співатиму джаз на радіо й загрібатиму гроші лопатою. (Salinger, 2012, p. 107).

(6) Eng.: I look like a fright (Salinger, 1953, p.143).

Rus.: Я сущее пугало (Salinger, 1983, p. 41).

Ukr.: Схожа на страшка (Salinger, 2012, p.109).

According to Ivushkina, one of the sociolinguistic markers of the British aristocracy speech is inclusion of slang (Ivushkina, 1998, p.105). Thus, the informal phrases: heaps of money and I look a fright can also be regarded as a social marker of Esme's hyperlect. In both translations, the stylistic functions of informal speech are preserved. The informal phrases are rendered by applying alternative equivalents: куча денег, пугало in the Russian translation, and загрібатиму гроші лопатою, схожа на страшка in the Ukrainian translation. Thus, the tactic of applying the functional equivalents is used in both translations. It is doubtful, however, that this register shifting will be appropriately perceived and assessed by readers as belonging to aristocracy speech. The reason is that informal words are more likely perceived by readers as a marker of a low social status of a literary character.

In addition, Esme's original speech abounds in lexical repetitions: the word intelligent (used 4 times), intensifiers quite (used 14 times), terribly (used 5 times), extremely (used 15 times). According to Leech (1969, p. 76), verbal repetitions, used by creative writers serve the artistic purpose, that is why they require their reproducing in translation. The above-mentioned lexical repetitions increase the expressiveness of Esme's speech, emphasising her emotional state. As a vivid component of Esme's idiolect, the lexical repetition fulfils the psychological function. Moreover, Korobleva (2010) notes that lexical repetitions and intensifiers are the age markers of teenager's speech. The number of lexical repetitions and their equivalents are represented in Table 1.

Lexical repetitions can be rendered by means of "preservation, synonym, omission, substitution, paraphrase, announcing the repetition" (Buitkuvienè, 2012, p. 110), which can be

\begin{tabular}{c|c|c}
$\begin{array}{c}\text { Salinger (1953) “For Esme with love } \\
\text { and squalor”, number of repetitions }\end{array}$ & $\begin{array}{c}\text { Ukrainian translation by } \\
\text { Grygorenko, Ivahnenko (2012), } \\
\text { number of repetitions }\end{array}$ & $\begin{array}{c}\text { Russian translation by Mitina (1983), } \\
\text { number of repetitions }\end{array}$ \\
\hline Quite, 14 & Дуже, 4 & Довольно, 4 \\
\hline Terribly, 5 & Страшенно, 2 & Страшно, 2 \\
\hline Extremely, 15 & Найдзвичайно, 9 & Чрезвычайно, 15 \\
\hline Intelligent, 4 & Розумний, 2 & Интеллигентный, 3 \\
\hline
\end{tabular}

Table 1

Lexical repetitions and their equivalents in translation 


\section{Table 2}

Translation tactics of rendering lexical repetition applied in the Russian and Ukrainian translations regarded as translation tactics in our research. Our research yielded that the tactics of preservation, substitution and omission can correlate with the strategy of partial preservation of idiolect characteristics. The analysis of both translations showed that the most optimal tactic of rendering the lexical repetitions is preservation of repeated lexical terms. Therefore, preservation is employed in $61 \%$ of cases in the Russian translation and in $45 \%$ of cases in the Ukrainian translation (see Table 2).

\begin{tabular}{c|l|c|c|c|c|c}
\hline $\begin{array}{l}\text { Language of } \\
\text { translation }\end{array}$ & $\begin{array}{c}\text { Translation } \\
\text { tactics }\end{array}$ & $\begin{array}{c}\text { Translation } \\
\text { of extremely }\end{array}$ & $\begin{array}{c}\text { Translation } \\
\text { of quite }\end{array}$ & $\begin{array}{c}\text { Translation } \\
\text { of terribly }\end{array}$ & $\begin{array}{c}\text { Translation } \\
\text { of intelligent }\end{array}$ & $\begin{array}{c}\text { Overall } \\
\text { tendency \% }\end{array}$ \\
\hline \multirow{2}{*}{ Russian } & Preservation & $100 \%$ & $29 \%$ & $40 \%$ & $75 \%$ & $61 \%$ \\
\cline { 2 - 7 } & Substitution & - & $64 \%$ & $20 \%$ & $25 \%$ & $27 \%$ \\
\cline { 2 - 7 } & Omission & - & $7 \%$ & $40 \%$ & - & $12 \%$ \\
\hline \multirow{2}{*}{ Ukrainian } & Preservation & $60 \%$ & $29 \%$ & $40 \%$ & $50 \%$ & $45 \%$ \\
\cline { 2 - 7 } & Substitution & $40 \%$ & $29 \%$ & $40 \%$ & $50 \%$ & $40 \%$ \\
\cline { 2 - 7 } & & - & $42 \%$ & $20 \%$ & - & $15 \%$ \\
\hline
\end{tabular}

The translation tactic of substitution is more frequently used in the Ukrainian translation for rendering the lexical repetition, e.g.,

(7) Eng.: You seem quite intelligent for an American (Salinger, 1953, p. 142).

Rus.: А вы кажетесь довольно интеллигентным для американца (Salinger, 2012, p. 40).

Ukr.: А ви здаєтесь досить розумним, як на американця (Salinger, 1983, p. 108).

(8) Eng.: Mother was an extremely intelligent person. Quite sensuous in many ways. (Salinger, 1953, p. 144).

Rus.: b) Мама была чрезвычайно интеллигентный человек и весьма страстная натура во многих отношениях. (Salinger, 2012, р. 41).

Ukr.: Мати була надзвичайно розсудливою жінкою. Чуттєвою багато в чому. (Salinger, 1983, p.110).

The Russian translator uses the adjective интеллигентный for rendering intelligent in the original text. Actually, these words do not mean the same: intelligent is "good at learning, understanding and thinking in a logical way about things; showing this ability" (Oxford Advanced Learner's Dictionary), while интеллигентньий is well-educated and cultured (Evgeneva, 1999). By way of stylistic and contextual analyses, we may conclude that the Russian translator's choice is justified. On the one hand, she preserves the repetition; on the other hand, the word интеллигентный in the little girl's mouth can sound incongruent, thus creating the desirable effect. The Russian translator uses the tactic of preservation of repetition, while the Ukrainian translators ignore the repetition and used different cognate words; therefore, the stylistic effect is weakened. In this case, the Ukrainian translators use the tactic of omission unjustifiably.

In addition, omission as a translation tactic is also used by translators for rendering the lexical repetition in the cases when a linguistic element does not have a semantic equivalent in TL. In this case, the translators face such translation difficulty as non-equivalent lexis. Thus, due to the polysemy of the adverb quite, it is challenging to preserve all the repetitions of the word. The Russian translator resorts to preservation while the Ukrainian translators ignore the repetition of the intensifiers quite and terribly. 
(9) Eng.: Mother was an extremely intelligent person. Quite sensuous in many ways (Salinger, 1953, p. 144).

Rus.: Мама была чрезвычайно интеллигентный человек и весьма страстная натура во многих отношениях (Salinger, 1983, p. 41).

Ukr.: Мати була надзвичайно розсудливою жінкою. Чуттєвою багато в чому (Salinger, 2012, p. 110).

(10) Eng.: Do you find me terribly cold? (Salinger, 1953, p. 144).

Rus.: А как вы находите, я страшно холодная натура? (Salinger, 1983, p. 41).

Ukr.: Ви вважаєте мене холодною особою? (Salinger, 2012, p.110).

The intensifier extremely is preserved in both translations (100\% in the Russian and $60 \%$ in the Ukrainian). The equivalents надзвичайно and чрезвычайно are appropriate to the intensifier extremely; they serve to increase the expressiveness and emotionality of Esme's speech and, therefore, help to reveal the inner world of Esme's personality and fulfil the psychological function of speech characterisation. Thus, the Russian translator is more careful in rendering the lexical component of Esme's idiolect, trying to preserve the lexical repetitions to the fullest extent. In the cases when it is impossible to preserve all motivated repetition, the Russian and Ukrainian translators apply the tactics of substitution and omission. It can be mentioned that the tactics of preservation, substitution and omission correlate with the strategy of partial preservation of idiolect characteristics.

Another specific feature of Esme's idiolect is the use of evaluative adverbs (purely, exactly, exceeding, beautifully, exclusively, dreadfully), e.g.,

(11) Eng.: I am dreadfully sorry about my hair (Salinger, 1953, p. 153).

Rus.: Ужасно жаль, что у меня такое с волосами (Salinger, 1983, p. 44).

Ukr.: Я страшенно вибачаюсь за своє волосся (Salinger, 2012, р. 116).

We can conclude that this group of lexical units makes Esme's speech more expressive. Moreover, according to Potapov (2002, p. 259), evaluative adverbs can be regarded as a marker of female gender of a literary character. The speech of a woman can be characterised as evaluative and emotional. The Russian and Ukrainian translators successfully cope with the task and find appropriate equivalents, using the tactic of parallel translation.

Analysis of challenges in rendering Esme's idiolect on the syntactical level shows that she uses alternatives questions and imperatives, e.g.,

(12) Eng.: Charles, do sit up! (Salinger, 1953, p. 153).

Rus.: Чарлз, а ну-ка сядь! (Salinger, 1983, p. 41).

Ukr.: Чарльзе, ну ж бо, сядь рівно! (Salinger, 2012, р. 111).

(13) Eng.: Now, just stop, please! (Salinger, 1953, p. 153).

Rus.: Нy, довольно! Прекрати, пожалуйста. (Salinger, 1983, p. 42).

Ukr.: Ну ж бо, припини це, будь ласка! (Salinger, 2012, p. 113).

While talking to her brother Charles, Esme uses imperatives, which can be regarded as a marker of her young age. Imitating adult speech, Esme pretends to sound more independent and decisive. The Russian and Ukrainian translators resort to tactic of parallel translation for rendering imperatives.

Another specific feature of Esme's idiolect on the syntactical level is the use of alternative questions, e.g.,

(14) Eng.: You go to that secret Intelligence school on the hill, don't you? (Salinger, 1953, p. 142).

Rus.: Вы ходите в эту секретную школу для разведчиков -- там, на холме, да?

(Salinger, 1983, p. 40).

Ukr.: Ви з таємної школи розвідників, що на горі, правда ж? (Salinger, 2012, p. 107). 
The Characteristic Traits of Corporal Clay's Idiolect
The analogue language means of TL (imperatives, alternative questions) are used in both translations. Thus, the Russian and Ukrainian translators preserve the characteristic traits of Esme's speech on the syntactical level, by applying the tactic of parallel translation.

Having analysed all the specific traits of Esme's hyperlect (phonetic mistakes in the words, inclusions of foreign words, bookish words, informal phrases, evaluative adverbs, intensifiers, lexical repetitions, misuse of words, imperatives, alternative questions), we may conclude that the Russian and Ukrainian translator face such translation challenges as phonetic distortions of words, non-equivalent lexis and non-standard syntax. Rendering the phonetic specific features of Esme's idiolect, the Russian translator resorts to the strategy of maximum preservation of idiolect characteristics and the tactic of phonetic matching, while the Ukrainian translators apply the strategy of partial preservation of idiolect characteristics and the tactic of omission. Rendering the lexical specific features of Esme's idiolect, the Russian and Ukrainian translators resort mostly to the strategy of maximum preservation of idiolect characteristics, using the tactic of parallel translation and the tactic of applying the functional equivalents. However, coping with the translation of lexical repetition, the Russian and Ukrainian translators managed to preserve them partially. Therefore, the strategy of partial preservation of idiolect characteristics and the tactics of preservation, substitution and omission were applied. Moreover, it should be mentioned that the Russian translator was more careful in rendering lexical repetition in Esme's speech, using mostly the tactic of preservation. Coping with the syntactical specific traits of Esme's idiolect, the Russian and Ukrainian translators resort to the strategy of maximum preservation of idiolect characteristics, In the framework of this strategy the tactic of parallel translation was employed.

The second part of the story, which the author himself ironically called the squalid part, acquaints the readers with a new character, the narrator's companion Corporal Clay. The scene of the second part is laid in Bavaria, Germany, close to the end of World War II. The war has brought the narrator to the edge of a complete nervous breakdown, from which only Esme's letter saves him. Corporal Clay is a 24-year old, uneducated American, whose speech makes him easy to remember. Being abrupt, expressive, faltering, full of invectives and vulgar words, Clay's speech fulfils the characterising and distinctive functions. Clay's idiolect reflects the social markers of a poorly educated person and can be regarded as a sociolect of underclass. Such variation of sociolect can be attributed to non-literary speech, which is represented in the original text by deviations from the literary norm on the phonetic, lexical, and syntactical levels. Clay's idiolect is constructed in contrast to Esme's hyperlect, fulfilling in such a way the contrasting function. The following deviations from the literary norm can be singled out on the phonetic level, e.g.,

- Dropping sounds and syllables (pronunciation problems): 'em (instead of them), goin', tellin', layin', talkin', writtin', comin', G'night, c'mon.

- Merging words: a) nouns + personal pronouns: willya (will you); b) nouns + preposition: helluva (hell of), kinda (kind of); c) verb + preposition: oughta (ought to), gotta (got to), coupla (couple of), wanna (want to); d) preposition + preposition: outa (out of).

Rendering Clay's idiolect, the Russian and Ukrainian translations face such translation difficulties as phonetic distortion of words (dropping sounds), non-equivalent lexis (merging words) and non-standard syntax (parentheses). It should be mentioned that deviations on the phonetic level are systematically ignored by the Russian and Ukrainian translators, which distorts, to an extent, the author's portrait of Clay. Thus, the target readers do not perceive the linguistic personality of Clay in the same way as the source readers. The social markers of low standard 
of education are lost in his translated speech together with the stylistic effect. Only in one case, the Ukrainian translators resort to the tactic of phonetic matching with the help of graphon Д' браніч, reproducing the phonetic deviation of the phrase G' night. Kukharenko (2003, p. 14) defines graphon as "intentional violation of the shape of a word (or word combination) used to reflect its authentic pronunciation." Unfortunately, the proposed alternative does not sound natural in Ukrainian and is practically unpronounceable unlike its English counterpart. Thus, rendering the phonetic deviations in most cases, the Russian and Ukrainian translators apply the tactic of compensation in the framework of which phonetical deviations are reproduced by the units of the lexical level, such as colloquialisms. The Russian and Ukrainian translators follow the theoretical approach of Vlakhov and Florin (1980, p. 258), who claim that, in the case of the absence of equivalents or functional analogues for deviation from the literary norm, the translator can resort to colloquialisms, which will give the translated text the necessary characteristics of deviation from the literary norm, e.g.,

(15) Eng.: Her goddam brother's gettin' outa the Navy on account of his hip (Salinger, 1953, p. 164).

Rus.: Этот сукин сын, ее братец, смывается с флота - бедро у него повреждено (Salinger, 1983, p. 47).

Ukr.: Ії чортів братик полишає флот через те, що у нього кепсько зі стегном (Salinger, 2912, p. 124).

(16) Eng.: They got this terrific show comin' on the radio in a coupla minutes. Bob Hope, and everybody (Salinger, 1953, p. 163).

Rus.: Через минуту по радио колоссальное обозрение. Боб Хоуп и еще всякие (Salinger, 1983, p. 46).

Ukr.: За кілька хвилин почнеться ота жахлива радіопередача. Там буде Боб Гоуп та всі інші люди (Salinger, 2012, р. 123).

These deviations from the literary norm on the phonetic level in the ST are partially compensated for in TT by the felicitous finds on the vocabulary level. Stylistic and translation analyses of the TT and ST make it possible to determine the extent of stylistic violations in the translation texts and to evaluate the gains and losses of the chosen translation tactic. The Russian translator uses informal смыввается, which creates the desirable effect of informal speech. The Ukrainian translators use the diminutive noun братик for derogative purpose, which can be regarded as a gain of the Ukrainian translation. It is worth mentioning that the word кепсько adds the low colloquial tonality to the utterance. However, the word terrific was mistaken to have a negative meaning and translated as жахливий, while this word is a marker of informal speech and widely used in the meaning of tremendous. The Russian translator is more careful in rendering the original text though she did not make a good choice in reproducing the word show by a formal обозрение. Thus, the tactic of compensation is widely used in both translations. It gives us grounds to claim that the Russian and Ukrainian translators apply the strategy of partial preservation of idiolect characteristics.

On the lexical level, the deviations from the literary norm are manifested in repetitions of emphatic epithet (goddam), intensifiers (hell, terrific), invectives (son of the bitch, bastard), the degree of expressiveness and the translation of which depend upon the context, e.g.,

(17) Eng.: Hey. I was just tellin' that new son of a bitch, Bernstein, downstairs. Re member that time I and you drove into Valognes, and we got shelled for about two goddam hours, and that goddam cat I shot that jumped up on the hood of the jeep when we were layin' in that hole? Remember? (Salinger, 1953, p. 166). 
Rus.: Эй, я сейчас рассказывал внизу этому дерьмовому новичку, Бернстайну. Помнишь, в тот раз приехали мы с тобой в Валонь, и два часа нас обстреливали как проклятых, и тогда эта проклятущая кошка как вскочит на капот джипа мы еще лежали в той яме, - я ее и подстрелил, помнишь? (Salinger, 1983, p. 48).

Ukr.: Агов, я саме розповідав унизу тому сучому сину, новенькому, Бернштейну. Пригадуєш, як ми двоє в"їжджали у Валонь, і нас цілісінькі дві кляті години вкривало бомбардуванням, й я застрелив того бісового котяру, що заплигнув на капот джипа, коли ми лежали долілиць у канаві? Пригадуєш? (Salinger, 2012, p. 126).

These lexical units as a component of Clay's idiolect fulfil the psychological function, highlighting the excited state of the speaker. The above-mentioned examples demonstrate that the Russian translator is more careful in rendering the lexical repetition of the words which are socially marked. The tactic of preservation is widely employed, while the Ukrainian translators resort to substituting different synonyms for the repeated words, e.g. клят $i$ and бiсовi for goddam, applying the tactic of substitution.

Another specific feature of Clay's idiolect is the use of over-familiar forms, such as listen ya, bastard, c'mon down, hey, what the hell are you talkin' about.

(18) Eng.: Listen ya, bastard (Salinger, 1953, p. 166).

Rus.: Слушай, ты, гад (Salinger, 1983, p. 47).

Ukr.: Послухай, ти, падлюко (Salinger, 2012, p. 126).

(19) Eng.: What the hell are you talkin' about? (Salinger, 1953, p. 167).

Rus.: Что ты мелешь? (Salinger, 1983, p. 48).

Ukr.: Про що це в біса ти говориш? (Salinger, 2012, p. 127).

These phrases are the markers of highly emotional speech. Thus, over-familiar forms fulfil the psychological and distinctive functions of speech characterisation. Moreover, according to Potapov (2002, p. 102), over-familiarity is one of the markers of male gender, which needs the exact rendering in translation. Both translators resort to preservation of over-familiarity in Clay's speech and use the tactic of preservation.

The syntactical level can be illustrated by the following deviations from the literary norm: grammatically incorrect constructions of questions and inconsistency of verb forms: Ya writin' letters? Ya know that? The what? Remember? Yeah? Wanna go? How much weight ya lose? Both translators use the tactic of compensation with the help of lexical units, e.g.,

(20) Eng.: "No kidding, hey. I goddam near fainted when I saw you at the hospital. You looked like a goddam corpse. How much weight ya lose? How many pounds? Ya know?" (Salinger, 1953, p. 163).

Rus.: Эй, кроме шуток. Я чуть не сомлел, к чертям, когда увидал тебя в госпитале. Лежит - мертвец мертвецом, черт тебя подери. Сколько ты весу спустил, а? Сколько фунтов? Ты сам-то знаешь? (Salinger, 1983, p. 47). Ukr.: Агов, без жартів. Я, трясця, геть не зомлів, як побачив тебе у шпиталі. Дідько, ти ж був як труп. На скільки ти схуд? Скіки кіло? Знаш? (Salinger, 2012, p, 124).

Rendering grammatical mistakes on the syntactical level is a rather complicated task due to the differences in the grammatical structure of SL and TL. From Popovych's (2015) standpoint, grammatical mistakes in literary characters' speech are sometimes made up for by colloquialisms, but, in most cases, are not reflected in translation, thus causing the loss of markers 
of social status in the TT. The Russian translator uses the tactic of compensation by deviating from the literary norm with the help of colloquialisms and the words of a low register, in order to make up for the losses on the phonetic and syntactical levels. The Ukrainian translators substituted the grammatical mistake in the question Ya know by replacing it with the phonetic mistake in the words знаш, скіки, thus preserving their stylistic function. Thus, on the syntactical level, the tactic of compensation is widely used in the both translations.

The length of the sentences used by Clay is shorter, comparing to sentence length in Esme's idiolect. Clay's speech abounds in simple syntactic constructions and parentheses ya know, Christ, for Chrissake. The Ukrainian and Russian translators face the translation difficulty such as non-standard syntax and need to apply the appropriate equivalents to cope with the task. The Russian and Ukrainian translators use different means for rendering parentheses, e.g.,

(21) Eng.: Christ almighty (Salinger, 1953, p. 162).

Rus.: Так тебя и разэтак (Salinger, 1983, p. 46).

Ukr.: Боже всемогутній! (Salinger, 2012, p. 123).

(22) Eng.: Jesus! (Salinger, 1953, p. 163).

Rus.: Ух, черт! (Salinger, 1983, p. 47).

Ukr.: Святий Боже! (Salinger, 2012, p. 124).

Apparently, the Ukrainian translators try to preserve the original meaning of the religious concepts Jesus and Christ, while the Russian translator resorts to substitution. Applying a contextual analysis to the interpretation of both translated texts helps us to trace the time difference between the two translations. Thus, the Russian translation was made in Soviet era, while the Ukrainian translation is more modern. As rightly pointed out by Popovych (2015, p. 120), Soviet ideology required the utmost avoidance of biblical concepts and allusions. Thus, the Russian translator substitutes the biblical concepts with the conversational expressive phrases, applying the tactic of compensation. The Ukrainian translators make the translated text closer to the original and preserve the author's intention, using the tactic of preservation.

Summing up, it should be mentioned that Clay's idiolect is related to non-literary speech. As a typological variation of sociolect, Clay's idiolect has such specific features as the phonetic deviations of words, emphatic epithets, intensifiers, invectives, over familiar forms, incorrect question constructions, parentheses. To render Clay's idiolect, the Russian and Ukrainian translators applied the strategy of partial preservation of idiolect's characteristics, in the framework of which the motivated phonetic deviations from the literary norm were almost completely ignored. Within the strategy of partial preservation of idiolect's characteristic, the translators used the tactic of compensation of the phonetic and grammatical deviation, the tactic of preservation and substitution of the lexical repetition.

The article is focused on singling out the specific challenges in rendering idiolects of literary characters (phonetic distortion of words, non-equivalent lexis, non-standard syntax) and examining the relevant translations strategies and tactics that can be applied to ensure the faithful reproduction of the target text. Within the framework of the functional, anthropocentric and multidisciplinary approaches to the text interpretation, a comparative analysis of the original and translated texts was held. Stylistic, contextual and translation analyses were employed. The notions of idiolect and linguistic personality, typological variations of idiolect and its functions were investigated. Sociolect as a typological variation of idiolect was under analysis, and two specimens of sociolect such as hyperlect and non-literary speech were investigated. The challenges in rendering hyperlect and non-literary speech 
such as phonetic distortion of words, non-equivalent lexis, non-standard syntax were indicated. As seen from the research data, the Russian translators analyse the linguistic personalities and idiolects of Esme and Clay more precisely than the Ukrainian translators. While rendering the phonetic specific features of Esme's hyperlect, the Russian translator resorts to the strategy of maximum preservation of idiolect characteristics and the tactic of phonetic matching, while the Ukrainian translators apply the strategy of partial preservation of idiolect characteristics and the tactic of omission. When rendering the lexical specific features of Esme's idiolect, the Russian and Ukrainian translators resort to the strategy of maximum preservation of idiolect characteristics, using the tactic of parallel translation and the tactic of applying the functional equivalents. However, coping with the translation of lexical repetition, the Russian and Ukrainian translators managed to preserve them partially; therefore, the strategy of partial preservation of idiolect characteristics and the tactics of preservation, substitution and omission were applied. The Russian translators use the tactic of preservation (61\%), substitution (27\%) and omission (12\%); thus, the stylistic function of the hyperlect coincides with the author's intent. The Ukrainian translators employed the tactic of preservation (45\%), substitution (40\%), and omission (15\%) for rendering lexical repetitions. When rendering the syntactical specific traits of Esme's idiolect, the Russian and Ukrainian translators resort to the strategy of maximum preservation of idiolect characteristics and the tactic of parallel translation.

When rendering the sociolect of Clay, the Russian and Ukrainian translators used the strategy of partial preservation of idiolect characteristics, neglecting the phonetic deviations from the literary norm in Clay's speech. It is connected with the tendency of applying the tactic of compensation on all language levels. Within the strategy of partial preservation of idiolect characteristics, the tactics of compensation, substitution and preservation were used. The result of the present research can be used in further investigations of literary characters' idiolects and for development of new translation strategies and tactics of rendering idiolects in translation of literary works.

\section{References}

1 Andrienko, T. (2016). Lost and found in translation: translation strategies for representing the author's individual style in belles-letters. Style and Translation, 1(3), 220-230.

2 Alekseitseva, T. (2017). Inoyazychnye vkraplivaniya $v$ perevode [Foreign inclusions in translation]. Problemy Sovremennoj Nauki i Obrazovaniya, 1(83), 80-84. Doi: 10.20861/2304-2338-2016-83

3 Babkin, A. (1966). Inoyazychnye Vyrazheniya v Sostave Russkoy Frazeologii. Problemy Sovremennoy Filologii [The Foreign Expressions in the Russian Phraseology. Problems of Modern Philology]. Moscow: Prosveshchenie.

4 Bassnett, S., \& Lefevere, A. (1990). Translation, History, and Culture. London, New York: Printer Publishers.
5 Bogdanova, E. (2011). O nekotoryh aspektah izucheniya termina idiolekt $v$ otechestvennoj i zapadnoj lingvistike [About some aspects of the study of idiolect in domestic and foreign linguistics]. Vesnik Leningradskogo gos. un. im. A. S. Pushkina, 100-108.

6 Borunov, A., \& Malygin, V. (2013). Sredstva sozdanija rechevoj portretnoj harakteristiki personazhej $v$ tvorchestve R. N. Mitry [The means of creating the speech portrait characteristics of the personages in the creative writing by R. N. Mitra]. Filologicheskie Nauki. Voprosy Teorii i Praktiki, 8 (26), 34-37.

7 Buitkuvienè, K. (2012). Strategies for translating lexical repetition in contemporary novels for teenagers. Kalbų Studijos / Studies about Languages, 20, 109-117. Doi: 10.5755/j01.sal.0.20.1317 https://doi.org/10.5755/j01.sal.0.20.1317 
8 Chalker, S., Weiner, E., et al. (1994). Oxford Dictionary of English Grammar. New York: Oxford University Press.

9 Evgeneva, A. (Ed.). (1999). Slovar Russkogo Yazyika [Dictionary of the Russian Language]. Moscow: Poligrafresursy.

10 Fedorov, A. (2002). Osnovy Obshchey Teorii Perevoda [Fundamentals of the General Theory of Translation]. Moskow: Izdatelstvo literatury na inostrannykh yazykakh.

11 Formica, D. (2006). Translating idiolects: Natalia Ginzburg's Lessico famigliare. Monash University Linguistics Papers, 5(1), 17-25.

12 Gromyak, R., \& Kovaliv, U. (Eds.) (1997). Literaturoznavchyi Slovnyk-dovidnyk [The Literary Studies Dictionary-reference Book]. Kyiv: VTS Akademia.

13 Honey, J. (1997). Language is Power: The Story of Standard English and Its Enemies. London: Faber and Faber.

14 Honey, J. (1998). Sociophonology. In F. Coulmas (Ed.), The Handbook of Sociolinguistics (pp. 92-107). Oxford: Blackwell. https://doi. org/10.1002/9781405166256.ch6

15 Ivushkina, T. (1998). Sotsiolingvisticheskiy aspect razvitiya angliyskoy rechi (na material rechevoy harakteristiki predstaviteley britanskogo vysshego klassa v angliyskoy hudozhestvennoy literature [Sociolinguistic Aspects of English Speech Development (on the material of speech characteristics of British high class representatives in English fiction)]. Moscow: MGLU.

16 Karasik, V. (2002). Yazykovoy Krug: Lichnost', Kontsepty, Diskurs [Language Circle: Personality, Concepts, Discourse]. Volgograd: Peremena.

17 Karaulov, Yu. (1987). Russkiy Yazyk i Yazykovaya Lichnost' [Russian Language and Linguistic Personality]. Moscow: Nauka.

18 Komissarov, V. (1990). Teoriya Perevoda (Lingvisticheskie Aspekty) [Translation Theory: Linguistic Aspects]. Moscow: Vysshaya shkola.

19 Koptilov, V. (1982). Teoriia i Praktyka Perekladu [Translation Theory and Practice]. Kyiv: Vyshcha shkola.

20 Korobleva, N. (2010). Peredacha vosrastnyh i gendernyh osobennostey idiolekta (pri peredache hudozhestvennoy literatury s angliys- kogo yazyka na russkiy [Rendering age and gender peculiarities of an idiolect (when translating fiction from English into Russian)]. Synopsis of candidate's dissertation in philology. Moscow.

21 Korobleva, N. (2017). Sohraneniye idiolekta literaturnyh personazhey v perevode: foneticheskiy aspect [Preservation of idiolect of literary characters in translation: phonetic aspect]. Bulletin of Moscow State Linguistic University. Humanitarian Sciences, 4(772), 220-224.

22 Kubryakova, E. (1995). Evolyutsiya lingvisticheskikh idey vo vtoroy polovine XX veka (opyt paradigmalnogo analiza) [The evolution of linguistic ideas in the second half of the 20th century (paradigm analysis experience)]. In Stepanov, Yu. S. (Ed.), Yazyk i Nauka Kontsa XX veka. Moskow: Rossiyskiy gos. un.

23 Kukharenko, V. (2003). Praktykum zi Stylistyky Anglijskoyi Movy. Pidruchnyk [Practising the English Language Stylistics. A Practical Manual]. Vinnycia: Nova Knyha.

24 Leech, N. (1969). A Linguistic Guide to English Poetry: English Language Series. London: Longman.

25 Leontiev, A. (2003). Osnovy Psyholingvistiki [Fundamentals of Psycholinguistics]. Moscow: Smysl.

26 Longman Dictionary of Contemporary English. [viewed November 2019]. Retrieved from https://www.ldoceonline.com/dictionary/ squalor.

27 Lyutikova, V. (2000). Lingvisticheskaya lichnost': Idiolect i dialect [Linguistic personality: Idiolect and dialect]. Doctoral dissertation (Philology). Yekaterinburg.

28 Matsko, L. (2003). Metodolohiia i Mmetody Stylistyki [Methodology and stylistics methods]. Kyiv: Vyshcha shkola.

29 Merriam Webster Dictionary. [viewed November 2019], Retrieved from https://www.merriam-webster.com/dictionary/gregarious.

30 Naumov, V. (2006). Lingvisticheskoe Opredelenie Lichnosti [Linguistic identification of personality]. Moscow: Dom Knigi.

31 Nekriach, T., \& Kopyl'na, O. (2002). Vidtvorennya kontaminovanoyi movy $v$ ukrayins'kykh perekladakh [Reproducing a Contaminated 
Language in Ukrainian Translations]. Problemy Semantyky, Prahmatyky ta Kohnityvnoyi Linhvistyky: zb. Naukovykh Prats, 1, 155-159.

32 Nekriach, T. (2015). Between Scylla of domestication and Charybdis of foreignization: A road to the reader. In Abstracts of the 8th International Conference "Major Issues in Translation Studies and Translator/Interpreter Training. Vinnytsia: Nova Knyha.

33 Advanced Learner's Dictionary. [viewed November 2019]. Retrieved from https://www. oxfordlearnersdictionaries.com/us/definition/ english/intelligen

34 Popovych, Yu. (2015). Challenges in rendering social status markers in the translation of the XIX century English fiction. Science and Education a New Dimension. Philology, 3(14), 17-20.

35 Potapov, V. (2002). Sovremennoe sostoyanie gendernyih issledovaniy $\mathrm{v}$ angloyazyichnyih stranah [The modern state of gender studies in English-speaking countries]. In Gender as a Gnoseological Intrigue. Gender Studies in Linguistics, Literature Studies and Theory of Communication. Moscow: MGLU.

36 Rebrii, O. (2012). Suchasni kontseptsiyi tvorchosti u perekladi: monohrafiya [Modern Arts Concepts in Translation: monograph]. Kharkiv: KhNU imeni V. N. Karazina Publ.

37 Rodionova, M. (2018). Characterization through speech in fiction and literary translation. Journal of Siberian Federal University. Humanities and Social Sciences, 5(11), 823-832. https://doi. org/10.17516/1997-1370-0273

38 Rybicki, J. (2006). Burrowing into translation: Character idiolects in Henryk Sienkiewicz's trilogy and its two English translations. Literary and Linguistic Computing, 21(1), 91-103. https://doi.org/10.1093/llc/fqh051

39 Sackmann, R. (2008). Explorations in Integrational Linguistics. Four Essays on German, French, Guarani. Amsterdam: John Benjamins
Publishing Company. https://doi.org/10.1075/ cilt.285

40 Saldanha, G., \& O'Brien, Sh. (2013). Research Methodologies in Translation Studies. New York: Routledge. https://doi. org/10.4324/9781315760100

41 Salzmann, Z. (2007). Language, Culture, and Society. An Introduction to Linguistic Anthropology. Boulder: Westview Press.

42 Shcherbak, A. (2015). Idiolect of fiction character in translation. Science and Education a New Dimension. Philology, 3(14), 25-27.

43 Tarnaeva, L. P. (2008). Kontseptsia yazykovoy lichnosti v kontekste problem perevodovedeniya [The concept of a linguistic personality in the context of problems of translation studies]. Bulletin of A.S. Pushkin Leningrad State University, 2(13), 55-70.

44 Vinogradov, V. (1990). Idiolect. In Yartseva, V. (Ed.), Linguistic Encyclopedic Dictionary. Moscow: Soviet Encyclopedic.

45 Vlakhov, S., \& Florin, S. (1980). Neperevodimoye $\checkmark$ Perevode [The untranslatable in translation]. Moscow: Mezhdunarodnye otnoshenia.

46 Vorozhbitova, A. A. (2007). "Yazykovaya lichnost" i "literaturnaya lichnost" kak lingvisticheskiye kategorii ["Linguistic personality" and "literary personality" as linguistic categories]. Linguistic Paradigm: Theoretical and Applied Aspects, 8, 22-30.

\section{Sources}

1 Salinger, J. (1991). Nine Stories. Boston: Little, Brown and Co.

2 Salinger, J. (1983). Devyat' rasskazov [Nine Stories]: (translated by S. Mitina). Available at: https://www.100bestbooks.ru/files/ Selindzher_Devyat_rasskazov.pdf [Viewed November 2019].

3 Salinger, J. (2012). Devyat' opovidan' [Nine Stories]: (translated by Yu. Grygorenko, A. Ivakhnenko). Kharkiv: Folio.

\section{Santrauka}

\section{Olha Sung. Literatūrinių personažų idiolektų vertimo iššūkiai}

Straipsnyje demesys sutelkiamas i literatūrinių veikejjų idiolektų vertimo iššūkius. Idiolektas, kaip personažų kalbėsenos apibūdinimo priemonè, tyrèjams suteikia galimybę pažvelgti i personažus kaip i kalbines asmenybes. Idiolektai gali atlikti keletą funkcijų: lyginamają, psichologinę, skiriamają ir apibūdinamają. Irodyta, kad vientisą veikèjo paveikslą imanoma 
sukurti tik atsižvelgus i jo idiolekto ypatumus, kurie padeda skaitytojams atpažinti veikejju socialini statusą, amžių, išsilavinimą, lyti ir emocinę būseną. Šio straipsnio tikslas - nustatyti literatūrinių veikejjų idiolektų vertimo iššūkius, tokius kaip fonetinis žodžių iškraipymas, beekvivalentè leksika, nestandartinè sintaksè ir apžvelgti idiolektų perteikimo kitomis kalbomis strategijas ir taktikas. Šiems tikslams pasiekti panaudota originalo ir vertimo tekstų lyginamoji analizè, kurios metu nustatytos kelios vertimo strategijos, tokios kaip maksimalus ar dalinis idiolekto savybiu išsaugojimas. Pritaikant maksimalaus idiolektu charakteristiku išsaugojimo strategijas, naudojamos lygiagretaus vertimo, funkcinių ekvivalentu taikymo ir fonetinio derinimo strategijos. Dalinio idiolektu charakteristiku išsaugojimo strategijos kontekste išskiriamos kompensavimo, praleidimo, išsaugojimo ir pakeitimo strategijos.

\section{Olha Sung}

PhD student at Professor O. M. Morokhovsky Department of English Philology, Translation and Philosophy of Language at Kyiv National Linguistic University, Ukraine

\section{Research interests}

Idiolect of fiction character, rendering accents and dialects of fiction character, sociolect, language personality, translation strategies and tactics

\section{Address}

Kyiv National Linguistic University, Professor O. M. Morokhovsky Department of English Philology, Translation and Philosophy of Language, 73, Velyka Vasylkivska St., 03680, Kyiv, Ukraine

\section{E-mail}

valek08515@gmail.com 